\title{
原践論女
}

\section{水位計自記紙の記録解像度が 流出水量の值に及ぼす影響について}

細田 育広1） 村上 亘 2) Roy C.SIDLE 3 )

\author{
1)森林総合研究所関西支所 \\ （７612-0855 京都市伏見区桃山町永井久太郎68） \\ 2) 森林総合研究所 \\ (テ305-8687 つくば市松の里1) \\ 3) 京都大学防災研究所地盤災害研究部門 \\ （勇611-0011 宇治市五ヶ庄）
}

釜淵森林理水試験地1号沢における水位計の変遷を例として，水位計自記紙の記録解像度が流出水量の值に及ぼす 影響を検討した．出水単位に区分した2000２004年の水位データ（単位データ）を1939～2004年における記録解像 度に対応した座標にスケーリングし, 読み取りの幅と角度を規定して水位波形の変曲点と正時の水位を抽出した. 抽出された水位データと単位データから計算された流出水量の差を誤差とし, 単位データの流出水量に対する百分 率で表した，記録解像度の影響はピーク前後のデー夕点位置に顕著に現れ，記録解像度が低いほど，水位変動の大 きい非積雪期に誤差の変動幅が大きくなった，出水単位の誤差は，形状指数 0.3 未満の出水で大きくなる傾向が認め られ，記録解像度が低い記録条件では最大 $30 \%$ を超えた。一方，年単位の誤差の合計は最大でも $1.2 \%$ 未満となっ た。このため当該流域で長期間の流出解析をする場合, 年単位の解析では目的に応じて補正の必要性を判断すれば 良いが, 出水単位の解析では記録解像度に応じた補正を検討する必要があると考えられた.

キーワード：記録解像度, アスペクト比, 形状指数, 長期観測, データ品質

\section{I 、はじめに}

森林の成長のように，長期的かつ緩慢な流域条件 の変化が水流出に及ぼす影響を調べる場合，気象条 件の年々変動を考慮すると, 出来るだけ長い期間の 流量データが必要である（蔵治, 2003)。しかし, 現 存の長期観測データは計測技術が進歩する中で蓄積 されてきたため, 観測期間を通じたデー夕品質が一 定といえる場合は少ないと考えられる。

一般に河川水量の観測は, 流量を直接かつ連続 的に観測することが困難なため，水位変動を記録 し, 水位一流量曲線を用いて流量換算する方法が とられる(吉野, 1997). 河川水位は, 流量の変化 のみならず河床変動の影響も受けるため, 正確な 観測のためには量水堰が用いられ，基準とする水 位標による直接測定の值で校正する方法が用いら れる，水位計は測定原理によりいくつかの方式に 分類されるが，古い時代には機械的な機構で記録 できる電源不要のフロート式自記水位計が一般的
であった（野満・瀬野, 1959).このタイプの水位計 は, 水位変動をフロートの上下動で検出し, 水位波 形を自記紙上にペンでアナログ記録する。流量は, 自記紙上の水位波形を離散化して計算される。その 際，アナログ記録された自記紙上の水位波形は, 変 動の緩やかな部分は毎正時等の一定時間間隔で, 変 動の激しい部分は波形の変曲点に応じたランダムな 時間間隔で読み取られるのが一般的であろう。ただ し, 変曲点は直線とみなされる区間の両端として判 断される。この時, 自記紙上の時間と水位の解像度 (記録解像度) によって水位波形の外見が変わるた め直線とみなせる区間も変わる。すなわち, 同一の 量水堰において水位を観測し, 決まったルールで水 位波形の離散化・流量計算を行っても, 流量の精度 は記録解像度に応じて大きく変わる可能性があると 考えられる.しかし, 記録解像度に基づく流量の誤 差について詳しく述べられた文献は見当たらない.

観測の目的と河川の流況に合わせて, 機種も記録 
解像度も最適な水位計の選択をするのが前提であ り, 記録解像度が問題になることは本来ありえない。 しかし，長期観測では老朽化対策のため水位計の更 新は避けられず，その間に計測技術も進歩するため 機種の変更も起こりうる. このため多くの長期観測 データは, 記録解像度の変更に伴うデー夕品質の摇 らぎを内包すると考えられる。これらによる記録解 像度変更の影響が無視できないほど大きければ，観 測期間を通じたデー夕精度の均質性を失わせ, 時系 列の連続性を切断する可能性がある (木下, 2004). 本来, 記録解像度を変更する場合, 流出水量の值に 対する影響を確認し, 必要であれば校正の方策を検 討するべきである。通常は記録解像度変更の際に新 旧の条件で並行観測し, 変更の影響を確認するはず であるが，その検討内容が公表されることは希であ る. 恐らく, これは観測者や研究者が個々に判断す る問題として扱われてきたためであろう。しかし最 初に述べたように，長期的かつ緩慢な流域条件の変 化と水流出の関係を, 現存の長期観測デー夕を用い て調べるためには, そのデー夕品質について検証し, 明らかにしておく必要があると考えられる。そこで, 水位計自記紙の記録解像度と流出水量の関係につい て定量的に明らかにすることを本研究の目的とした。

デー夕品質の検討にあたっては, 評価の基準とな るデー夕が必要である。流出水量の值には, 水位観 測・流量計算それぞれにおけるさまざまな誤差が含 まれるため, その測定・計算に関わるすべての要素 の精度を個々に高めて真值に近い值を求める必要が ある（高橋, 1978; Stevens Water Monitoring Systems, Inc., 1998). 水位波形の離散化にあたっては，水位 波形をできるだけ忠実にトレースすることがこれに 該当する。また，同一流域で記録解像度が異なる各 期間から水位波形が近似する出水を選び出して流出 水量を比較しても, 元々の水位波形が完全に一致す ることは無いため, 検討結果の信頼性は低い。これ らの点を踏まえ, 記録解像度以外の要素については 一定の精度となるように, 最も精度が高い水位デー 夕から記録解像度に応じた水位データを作成し，流 量計算の方法を統一して検討することとした。この 手法が適用可能な具体的な事例として, 本研究では 釜淵森林理水試験地（丸山・猪瀬, 1952）の1号沢 (以降, 釜淵 1 号沢) を取り上げた。釜淵 1 号沢は 1939年の観測開始以降, フロート式自記水位計によ る観測が継続され, 水位計自記紙の記録解像度の変 遷が明らかである。また, 量水堰と水位一流量曲線
に変更は無い。夏季には集中豪雨性の降雨があり, 明膫な積雪・融雪期のある小流域である。このため, 出水回数が多いとともに水位変動が大きく, 出水波 形のバリエーションが豊富なため本研究の目的には 都合が良い. 釜淵 1 号沢に扔いて最も精度が高いと考 えられる2000〜2004年の水位デー夕を基に，過去の 記録解像度に応じた水位デー夕を作成して検討した。

\section{II. 対象流域の概要}

気候条件や流域面積, 量水施設の構造などにより, 自記紙の記録解像度が流出水量の值に与える影響の 大きさは異なると考えられる。そこで対象とした流 域の自然条件および観測方法の概要について述べて おく.

\section{1. 自然条件}

釜淵1号沢（面積3.06 ha, 標高162 251 m, 平均 傾斜 $35^{\circ}$ ) は山形県北部 (北緯 $38^{\circ} 56^{\prime}$, 東経 $140^{\circ} 15^{\prime}$ 付近）に位置する。基盤地質は第三紀の凝灰岩質堆 積岩類, 土壤深は平均 $45.6 \mathrm{~cm}$ (A層 : $15.5 \mathrm{~cm}, \mathrm{~B}$ 層 : $30.2 \mathrm{~cm}$ ) である（丸山・猪瀬, 1952)。植生はブ ナ・ナラ類を主とする広葉樹に, 1916年までに植栽 されたスギ・ヒノキが混交する（農林省林業試験場, 1961)。冷温帯多雪地域にあるこの流域の平年の気象 条件は, 年降水量 $2405.6 \mathrm{~mm}$, 年平均気温 $11.1^{\circ} \mathrm{C}$, 最大積雪深 $153 \mathrm{~cm}$ である (細田・村上, 2006). 例 年1〜3月は $1 \mathrm{~m}$ 以上の積雪に覆われ，3月下旬～4月下 旬にかけては融雪による日中〜夕方の増水が観測さ れる。

2000～2004年に抢ける降水条件の概要を図一1に示 す. 対象期間の暦年降水量は平均 $2778.7 \mathrm{mm（2305.6〜}$ $3171.9 \mathrm{~mm}$ ) であり, 平年值より平均 $14 \%$ 程度多い. 年降水量に対する積雪期（1３月および12月）の降水 量の割合は最大 $46 \%$ （2000年）, 最低32％（2002 · 2004年) であり, 平均值38 \%は1938～1999年の平均值 $35 \%$ とほぼ変わらない. $0.5 \mathrm{~mm}$ 以上の降水が記録さ れた日数の期間割合は, 積雪期 $81 \%(75 \sim 88 \%)$, 非 積雪期（4～11月） $54 \%$ (49～58％) である. 1938〜 1999年の平均では, 積雪期 $69 \%$, 非積雪期 $46 \%$ であ る. 降水日数の期間割合は, 年降水量が多い分, 対象 期間の方がいずれも平均より $10 \%$ 前後多かった。 月 最大降水強度は, 積雪期は概ね $10 \mathrm{~mm} / \mathrm{hr}$ 以下となる が, 非積雪期は $10 \mathrm{~mm} / \mathrm{hr}$ を超え, 7 ・8月は平均で $20 \mathrm{~mm} / \mathrm{hr}$ 超えた。 


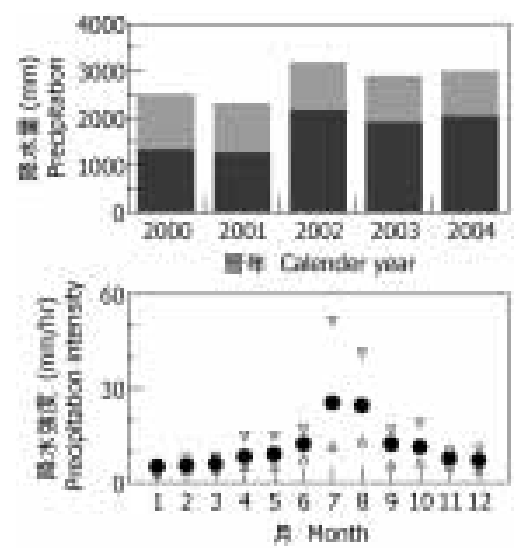

:4 11月, Apr.-Nov., $\square: 1 \sim 3 \cdot 12$ 月, Jan.-Mar. and Dec., 均值, Mean value, $\nabla$ : 最大值, Maximum value, $\triangle$ : 最小值, Minimum value.

図 - 1 対象期間における釜淵森林理水試験地の降水概況

Fig.1 General conditions of precipitation from 2000 through 2004 in Kamabuchi experimental watershed.

\section{2. 観測方法}

水位観測は1939年に始まり, 以来 $45^{\circ} \mathrm{V}$ ノッチ式の 量水堰堤に抏いて, フロート式自記水位計を用いて 行われている。過去65年間に，水位計の記録解像度 は5回変更された (表一 1$)$. 使用された三種類の水位 計のうち，スチーブンスF型水位計はペンが一定方向 に一定速度で移動し, 水位変化に応じて自記紙がペ ンの移動方向と直交する方向に動き水位を記録する。 これとは逆の機構で他の二機種は水位を記録する。 ペンと自記紙の動きは相対的な関係にあるので，本 稿では自記紙の時間軸が単位時間に移動する距離を
紙送り速度とした。

1960年代以前の水位計の紙送り機構はゼンマイ式 が多く, 時間精度に問題があったとされる（山口・ 斎藤, 1997). 対象流域でも同様の問題を抱えていた と考えられるが，こまめに巡視することで対処して きた。また対象流域では，厳冬期（概敉1月）に量 水槽水面が結水することがあるため, 厳冬期の水位 データの精度は現在でも低い場合がある。

1997年9月以降は測定水位を電圧出力できるポテ ンショメータ付きのフロート式自記水位計に更新さ れた。この後，ペンによる自記記録と並行して，10 分間隔でポテンショメータ出力が記録され, ペン記 録の読み取り值を 10 分間隔の值で補完した（細田・ 村上, 2006)。これにより時間精度が改善されるとと もに，観測史上最も忠実に水位波形がトレースされ るようになった。

自記紙上の水位波形は，基本的に大きな変曲点と 正時の水位を読み取り，基準となるポイントゲージ の值で校正されてきた。水位の読み取りは1985年1 月〜1997年8月はデジタイザが使用され，その期間 以外は目視によって行われた。

\section{III. 解析方法}

表一1における記号（A〜F）を用いて各期間の記録 解像度を表す．2000～2004年の水位デー夕を出水単 位に区分し, 記録解像度に応じた仮想的な水位デー 夕（期間条件デー夕）を作成した。得られた期間条件 データを用いて水位データの違いが流出水量にどの程

\section{表 -1 釜淵森林理水試験地1号沢における水位計記録解像度の変遷}

Table 1 Changes of chart resolution of the water-level gauge in Kamabuchi No. 1 watershed.

\begin{tabular}{|c|c|c|c|c|c|c|}
\hline $\begin{array}{c}\text { 記号 } \\
\text { Symbol }\end{array}$ & $\begin{array}{c}\text { 期間 (年/月) } \\
\text { Period } \\
\text { (year/month) }\end{array}$ & $\begin{array}{l}\text { 水位計機種 } \\
\text { Gauge type }\end{array}$ & $\begin{array}{c}\text { 紙送り速度 } \\
\text { Carriage } \\
\text { Speed } \\
(\mathrm{mm} / \mathrm{hr}) \\
\mathrm{X} \\
\end{array}$ & $\begin{array}{c}\text { 水位倍率 } \\
\text { Water level } \\
\text { magnification } \\
(\mathrm{m} / \mathrm{m}) \\
\mathrm{Y}\end{array}$ & $\begin{array}{c}\text { 記録解像度 } \\
\text { Chart } \\
\text { resolution } \\
(\mathrm{mm} / \mathrm{hr} \mathrm{m} / \mathrm{m}) \\
\text { X Y }\end{array}$ & $\begin{array}{l}\text { アスペクト比*1 } \\
\text { Aspect ratio*1 }\end{array}$ \\
\hline A & 1939/01-1955/04 & $\begin{array}{c}\text { 縦型原寸直読式 } \\
\text { Vertical actual scale }\end{array}$ & 19.0 & 1.0 & 19.0 & 19.0 \\
\hline B & $1955 / 05-1956 / 07$ & & 1.3 & 1.0 & 1.3 & 1.3 \\
\hline $\mathrm{C}$ & $1956 / 08-1961 / 10$ & スナーフンス & 5.2 & 1.0 & 5.2 & 5.2 \\
\hline $\mathrm{D}$ & $1961 / 10-1977 / 11$ & Stevens type F & 2.6 & 1.0 & 2.6 & 2.6 \\
\hline $\mathrm{E}$ & $1977 / 12-1997 / 08$ & 水研62 型 & 18.0 & 2.0 & 36.0 & 9.0 \\
\hline $\mathrm{F}$ & 1997/09-present & Suiken 62 type & 6.0 & 2.0 & 12.0 & 3.0 \\
\hline
\end{tabular}

*1 時間に相当する自記紙上の時間方向の長さ $(\mathrm{dx})$ と $1 \mathrm{~mm}$ の水位変化に対応する自記紙上の水位軸方向の長さ $(\mathrm{dy})$ の比 $(\mathrm{dx} / \mathrm{dy})$. Aspect ratio is defined as the length corresponding to one hour along the time axis divided by the length corresponding to a water-level change of 1 $\mathrm{mm}$ along the water-level axis of the recording chart. 
度の差を生じさせるのかを出水単位・年単位で解析 し, 流出水量に対する記録解像度の影響が大きくなる ハイドログラフ形状，および読み取り条件の影響につ いて検討した。 以下にその詳細を述べる。

\section{1. 期間条件に応じたデータの作成}

\section{1）出水単位の区分}

対象期間の水位データを, 初期水位 $1 \mathrm{~cm}$ 以上・増 水位 $1 \mathrm{~cm}$ 以上. 減水継続時間 10 時間の条件で出水単 位に区分した，出水単位とは基底流出を含めた水位 波形である. 多くの場合, 出水単位の終点は次の出 水単位の始点となる。これを単位データとした。対 象期間全体を通じて得られた出水単位は, ノッチ高 を超える出水（3個）を除いて，617個である。

\section{2）期間条件データ}

単位データを基に，条件 $\mathrm{A} \sim \mathrm{F}$ に応じた水位デー 夕を次のように作成した（図一2）.

まず，単位データの日時と水位を，各条件の紙送 り速度と水位倍率に応じた実寸座標上の点 $(x=$ 時刻, $y=$ 水位）に変換した。すなわち，日時は歴年ごとに 1 月 1 日午前 0 時を 0 時間として紙送り速度倍し，水位 は水位倍率を乗じて, 水位デー夕各点を $x$ と $y$ に変換 した．次に隣接する二つの座標点を結ぶ直線が成す 角 $(\alpha)$ ，および連続する二直線の交角 $(\theta)$ を次式で 求めた。

$$
\begin{aligned}
& \alpha_{i}=\tan ^{-1}\left(\frac{y_{i}-y_{i-1}}{x_{i}-x_{i-1}}\right) \\
& \theta_{i}=\left|\alpha_{i}-\alpha_{i+1}\right|
\end{aligned}
$$

ここで， $i$ : 座標点の順番を表す添え字.

目視により自記水位波形を離散化する場合，正時 の值を適宜読み取るとともに，水位変動が大きい部 分では出水の直前やピークなどの大きな変曲点をま ず拾い出し，その間で直線と見なせる区間の端点を なるべく細かく拾い出すのが一般的であろう。これ と概ね同じとなるように, 各座標点前後の直線の交 角が $30^{\circ}$ を超える座標点（基点, $\theta>30^{\circ}$ ) を抽出し, その基点間において時間方向が一定距離（読み取り

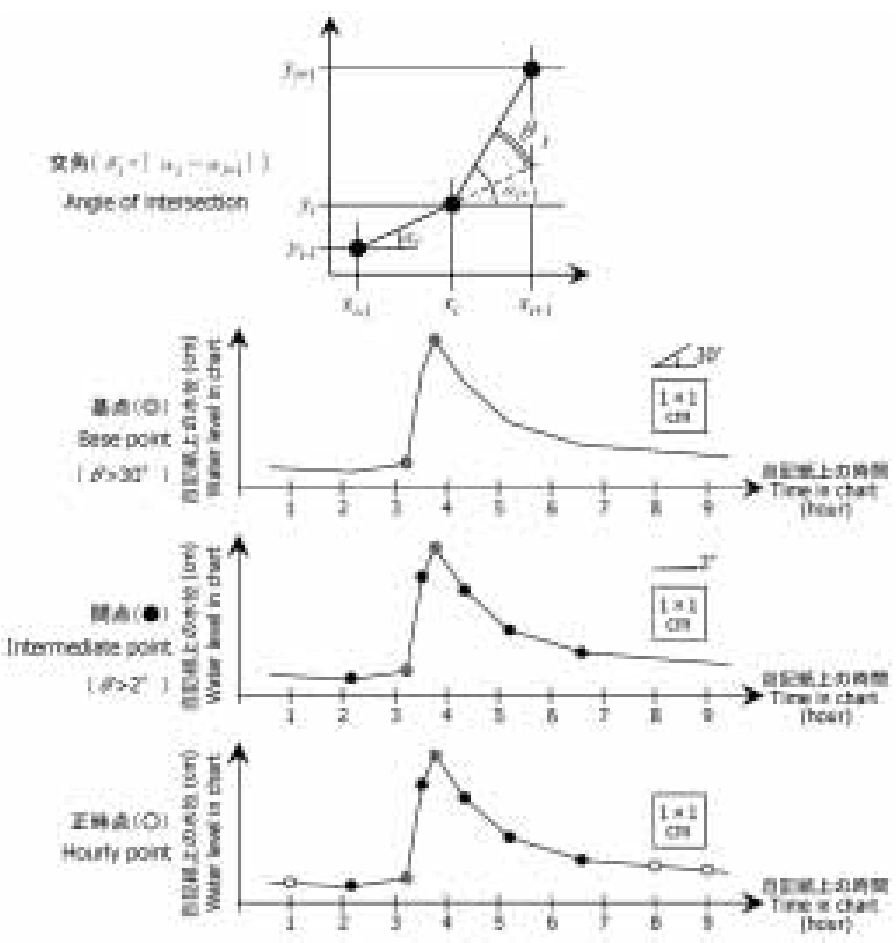

図の例では，2７時の正時点は基点・間点との距離が自記紙上の1時間未満のため読み取られない.

In this example, hourly points from 0200 to 0700 are not extracted because these hourly data lie within $1 \mathrm{~h}$ of the data shown on the graphs for base and intermediate points.

\section{図 -2 自記紙読み取りの概念図}

Fig.2 Schematic diagram of extracted points of the waveform. 
幅）以上離れ，かつ前後の直線の交角が一定角（読 み取り角）を超える座標点（間点）をすべて抽出し た (変曲点読み).ささらに, 変曲点読みで抽出された 各点間が読み取り幅の2倍以上離れている場合，1時 間相当の幅以上離れている正時の点を抽出した（正 時読み)。また, 出水単位の先頭と末尾のデータは必 ず加えた。

記録解像度が同じでも, 読み取り条件を変えるこ とで異なる水位デー夕が得られ, 流出水量の值に差 が生じる。このため記録解像度の影響を調べる目的 では，できるだけ忠実に水位波形をトレースする読 み取り条件を設定する必要がある。そこで基点を抽 出する交角は，水位波形を概観したとき確実に変曲 点として認識される最小の角度として $30^{\circ}$ を設定し た。また，読み取り幅は $1 \mathrm{~mm}$ ，読み取り角は $2^{\circ}(\theta>$ $2^{\circ}$ ) を基本とした。幅 $1 \mathrm{~mm}$ は実際に読み取りの限界 と考えられる幅よりもやや広めであるが，ペン記録 のインク幅を考えると読み取り精度上の限界に近い。 同様に交角 $2^{\circ}$ は，変曲点として目視で認識できるほ ほ限界といえるだろう。変曲点に近接する正時点は, 作業効率の点から読み取らない判断をする場合が多 いと考え，上述の条件で正時点を抽出した.

\section{3）流出水量}

釜淵1号沢の水位一流量曲線を用いて台形公式に より流出水量を計算する場合, 流出水量の精度を 1/100以上にするためには，積分区間の水位差を 1.3 倍以下にする必要がある（丸山・猪瀬, 1952)。この ためデー夕の時間間隔が長くなる期間条件では，そ もそも計算精度が低くなることが予想される。そこ で計算精度をそろえるため, 隣接する水位データの 時間間隔が10分以上ある場合はその間を直線とみな し，水位変動幅を時間案分して各積分区間の時間間 隔が最大でも10分となるようにした。流出水量の計 算には台形公式を用い，各積分区間の平均水位を流 量に換算し, 時間間隔との積を求め, 出水単位で合 計した値をその出水の流出水量とした。期間条件 デー夕に基づく流出水量の值から, 単位デー夕に 基づく流出水量（基準値）を引いた值を誤差とし た. 出水単位の誤差は, 基準值に対する百分率で 表し, 暦年等の期間単位の誤差は, 出水単位の誤 差の期間合計を同期間の基準值の合計で除した百 分率で表した。

\section{2. 出水ハイドログラフ形状の指数化}

出水ハイドログラフ形状を表す指数としては, 歪
度・尖度などの統計量 (神田・藤田, 1982), 出水八 イドログラフを近似させた関数の定数（たとえば Yue et al, 2002）等がある. 出水八イドログラフの 鋭敏さの指標として, ピーク流量と平均直接流量の 比が用いられた例もある(阿部ら，1982）。本研究で は，どのようなハイドログラフ形状のとき誤差に注 意しなければならないかを, 記録解像度ごとに大ま かに整理できれば良いと考え，八イドログラフの面 積比で表現される簡便な方法を用いた。すなわち， 次式によって得られる值を各出水単位における八イ ドログラフ形状の指数（形状指数: $S$ ) と定義した.

$$
\begin{aligned}
& q_{i}=f\left(\frac{h_{i}+h_{i+1}}{2}\right) \\
& S=\left(\frac{\sum_{i=1}^{m}\left(q_{i}-q_{0}\right) t_{i}}{\left(q_{\max }-q_{0}\right) \sum_{i=1}^{m} t_{i}}\right)
\end{aligned}
$$

ここで, $f:$ 水位一流量曲線の関数, $h$ :水位, $q$ : 流 量, $q_{0}$ : 出水単位の初期流量, $q_{\max }$ : 出水単位の最高 水位における流量 (最大流量), $t$ : 積分区間の時間 間隔， $i$ : 出水単位における積分区間の順番, $m: i=1$ から $q_{i} \geq q_{0}$ の範囲に抢ける出水単位の積分区間数. 計算には単位デー夕を用い, ひとつの出水単位にひ とつの形状指数が算出される.

急激に増水し, 急速に減水する単一ピークの出水 では，(4)式の分母が表す面積に比べて分子が表す面 積が相対的に小さくなるため, 形状指数は小さくな る。一方, 水位変動が緩やかな出水や, 水位変動が 急激でも複数のピークを有する出水では, 形状指数 の值は大きくなる傾向がある.

\section{IV. 結果}

\section{1. 期間条件データ}

各期間条件による水位データの抽出例を図ー3に 示す (各図右上の数值は各点の数). 単位時間当た りの水位変化が同じ場合，紙送り速度が小さいほど 交角は大きくなる。このため, 基点数は条件 $\mathrm{B} て ゙$ 最 も多く, 条件Aで最も少なかった。一方, 紙送り速 度が小さいほど，読み取り幅の制約を受けやすい。 このため間点数は，基点とは逆に条件Aで最も多く， 条件Bで最も少なくなった。特にピーク周辺では， 紙送り速度が小さい条件ほど間点が少なくなった。

図一4に水位デー夕の時間間隔の頻度分布を示す. 


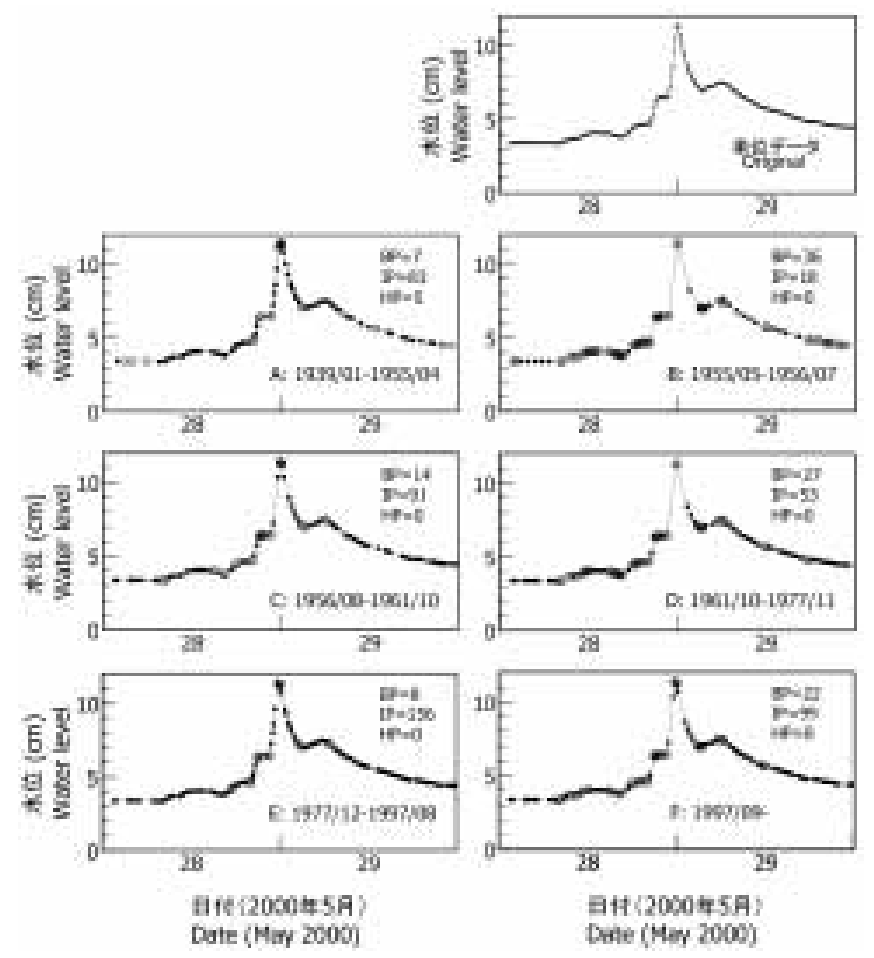

○: 基点(BP), Base point, O: 間点(IP), Intermediate Point, $\bigcirc$ : 正時点(HP), Hourly point.

図一3 抽出された水位デー夕の例

Fig.3 Examples of extracted water-level data based on chart resolution.
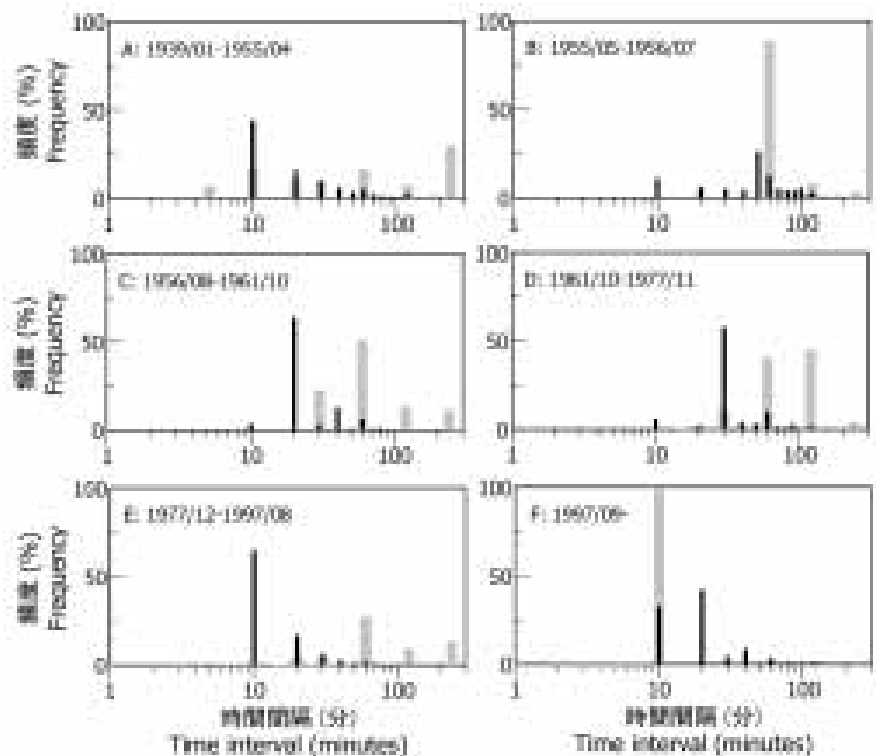

$\square:$ 実データ, Actual data,

：期間条件データ, Extracted data.

図－4 実際の水位データと期間条件に応じて作成したデータの時間間隔頻度分布

Fig.4 Histograms of the actual data and the extracted data classified by time interval. 
単位データを含む観測期間の実データは98％以上が 10分間隔であった。実データは基本的に毎正時を読 み取ってきたため，60分と30分の時間間隔の頻度が 高い。 また緩やかな減水過程では，2４時間の時間 間隔で水位波形が読み取られており，1時間の倍数に 当たる時間間隔の頻度も高くなっている。条件E期間 後半のデジタイザによる実データは, 正時読みの位 置が正時を挟んで数分ばらつくため頻度が分散する ものの, 目視による実データと比較して頻度分布の 傾向に大きな差は認められなかった。一方, 期間条 件デー夕は1時間以下の時間間隔に分布した。紙送り 速度が大きくなるにつれ, 短い時間間隔の頻度が高 くなる傾向が認められる。特に紙送り速度が $10 \mathrm{~mm} / \mathrm{hr}$ 以上の条件A・Eでは, 読み取り幅 $1 \mathrm{~mm}$ が 10 分未満に相当するため, 時間間隔10分の頻度が突出 した.

\section{2. 出水単位の誤差}

出水単位の誤差を出水開始時点の月別に示すと 図一5となる。月別にみると 5〜11月の誤差が大き
かった。期間条件別では, 紙送り速度が小さい条 件ほど誤差が大きい傾向が認められた。条件B（紙 送り速度最小）の誤差は最大 $30 \%$ を越え，条件 $\mathrm{A}$ （紙送り速度最大）ではすべての誤差がー0.5〜2.1\% の範囲に分布する。ただし，条件Fの紙送り速度は 条件Cよりも大きいが, その誤差は条件Cよりも大 きい傾向がある。

形状指数と出水単位の誤差の関係は, 形状指数が 概ね 0.3 未満の場合に誤差の大きい出水が増える傾 向が認められた (図一6). 紙送り速度が最も小さい 条件Bにおいては形状指数 0.1 未満, 条件Dでは形状 指数 0.07 未満になると誤差は $10 \%$ を越えた。紙送り 速度が $10 \mathrm{~mm} / \mathrm{hr}$ 以上の条件 $\mathrm{A} \cdot \mathrm{E}$ では, 形状指数が 小さい場合でも誤差は大きくならず，誤差は概ね $2 \%$ 未満でほぼ横ばいとなった。

複数のピークを有する出水の形状指数は, 水位変 化率が全般に大きい出水でも大きめの值になる傾向 があるため，複数ピークの出水の方が，単一ピーク の出水よりも，同じ形状指数に対する誤差が大きい 場合が多く認められた。条件 B・Dでは, 複数ピー
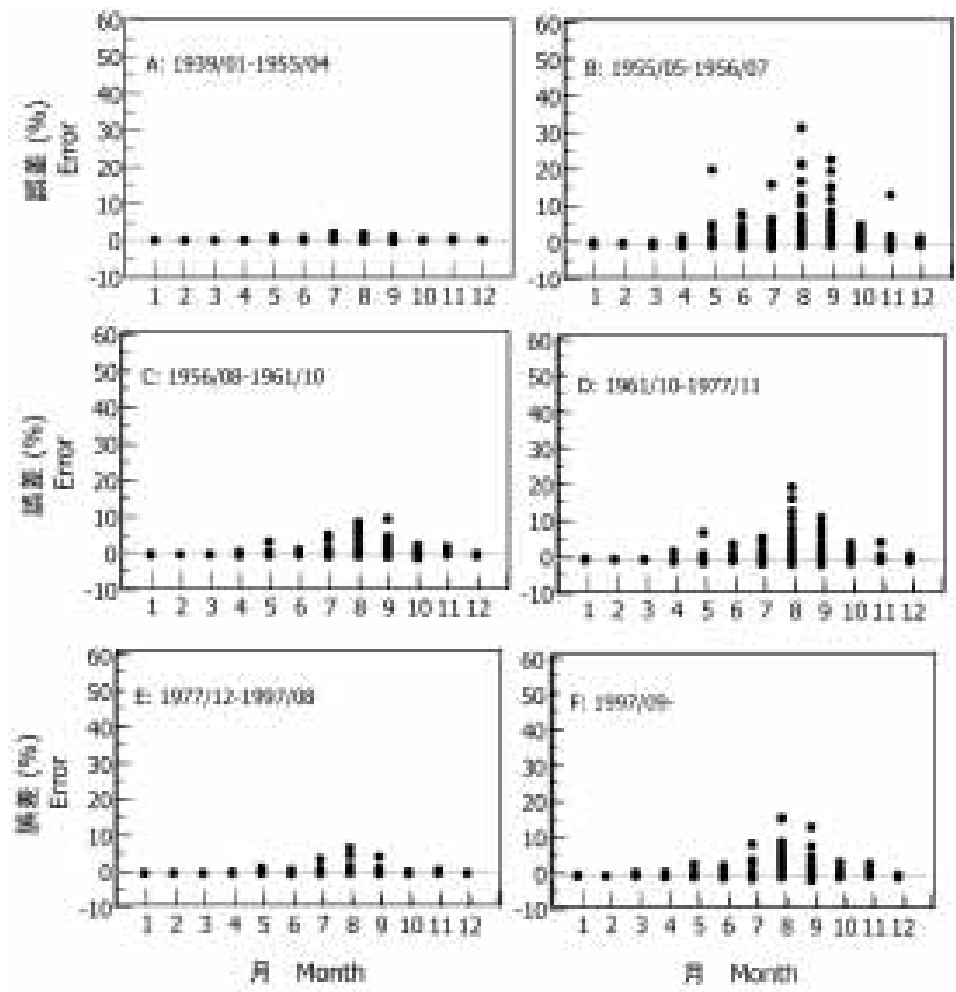

図-5 出水単位誤差の月別分布

Fig.5 Monthly distributions of unit flood errors. 

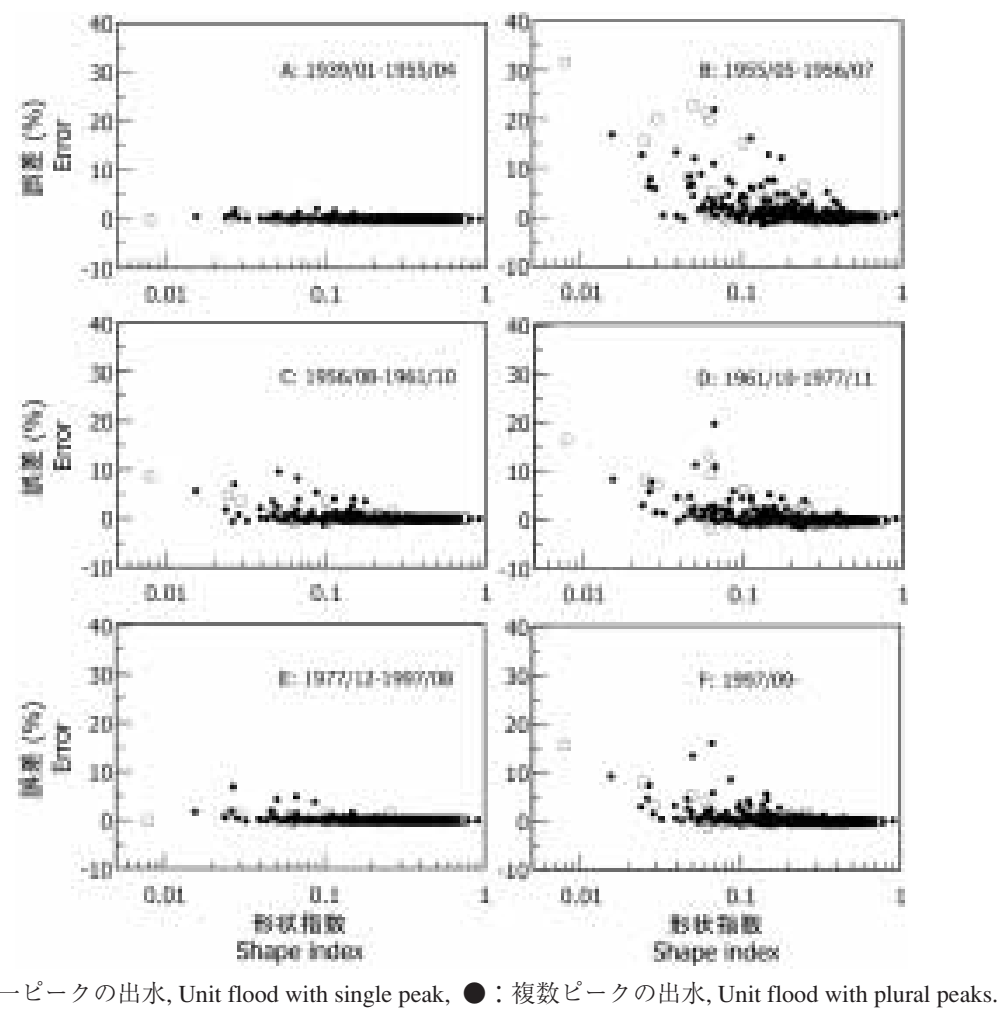

$\bigcirc$ : 単一ピークの出水, Unit flood with single peak,

複数ピークの出水, Unit flood with plural peaks.

図-6 出水ハイドログラフの形状指数と誤差の関係

Fig.6 Relationships between the shape indexes and unit flood errors.

クの出水の誤差が大きくなる形状指数は，0.3よりも やや大きい. 条件Fでも形状指数 0.07 未満で誤差 $10 \%$ 超える出水が認められた. しかし, 出水単位 に扔けるピーク数に関わらず，各期間条件における 誤差の分布範囲には大きな差が認められなかった.

\section{3. 年単位の誤差}

年単位の誤差は年により異なり, 対象期間の後半 ほど大きな值となった（図一7)。期間条件で比較す ると, 出水単位の誤差と同様, 条件 $\mathrm{C}$ 条件 $\mathrm{F}$ の関 係を例外として紙送り速度が小さい条件ほど年単位 の誤差も大きくなる傾向が認められた。条件 $\mathrm{B}$ の䛊 差は最大 $20 \mathrm{~mm}$ 越えている。しかし, 出水単位で 最大 30 \%あった誤差は，年単位では最大でも $1.2 \%$ 未満となった。

暦年を積雪期（1３・12月） · 非積雪期（4～11 月）で区分すると，積雪期の䛊差は暦年とは異なる 変動パターンを示し， $\pm 0.1 \%$ 範囲に分布した。 一方, 非積雪期の誤差は暦年とよく似た変動パター ンを示すが, 暦年よりも全体にやや大きな值となり,
最大值は $1.7 \%$ を越えた。

\section{4. 読み取り条件の影響}

ここまで，読み取り幅を $1 \mathrm{~mm}$ ，読み取り角を $2^{\circ}$ と した場合について述べてきた。この読み取り条件で 作成された水位デー夕は，実デー夕に比べると，か なり細かく水位波形をトレースしている(図一4). 実際の水位デー夕は，もう少し粗い条件で読み取ら れており，各読み取り条件の值を大きくした場合に 相当すると考えられる。また, 実際の読み取り条件 は記録解像度に応じて変化すると考えられる。ここ では表一1に扔ける記録解像度とアスペクト比を用い て, 読み取り条件の值を変えた場合の年単位の誤差 との関係について検討した。記録解像度は紙送り速 度と水位倍率の積である。アスペクト比は，1時間に 相当する自記紙上の時間軸方向の長さ $(\mathrm{d} x)$ と, $1 \mathrm{~mm}$ の水位変化に対応する自記紙上の水位軸方向の 長さ $(\mathrm{d} y)$ の比 $(\mathrm{d} x / \mathrm{d} y)$ とした.

読み取り幅を大きくすると, 記録解像度が高い条 件の誤差はあまり変わらず，低い条件の誤差が大き 


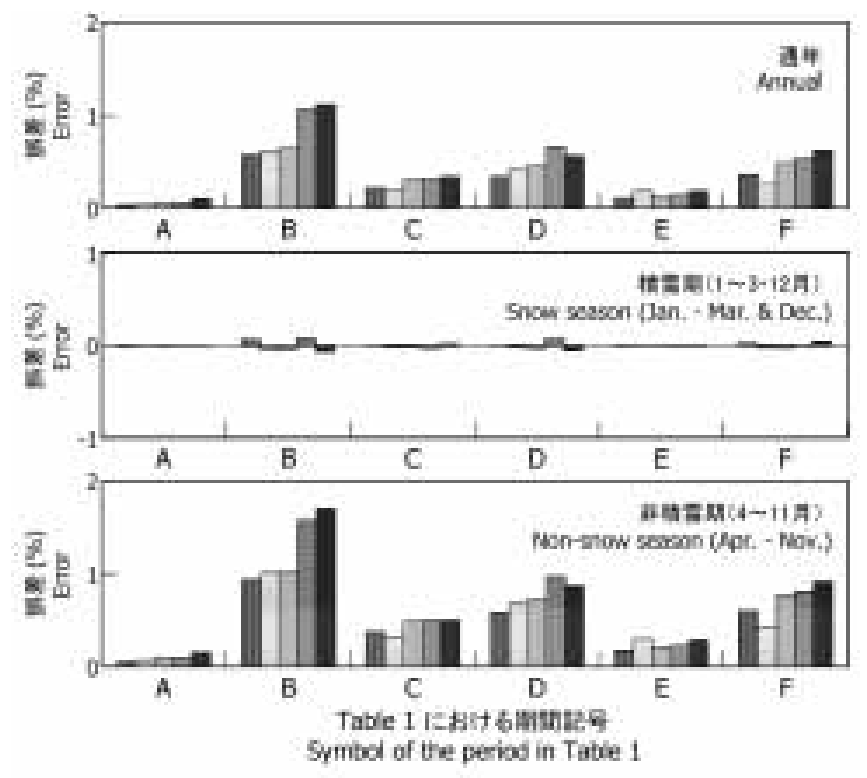

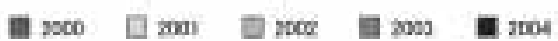

困 -7 年単位 $\cdot$ 積雪期 · 非積雪期の誤差

Fig.7 Errors for annual, snow season, and non-snow season flow records.

くなる傾向が認められた (図一8). 特に記録解像度 最小 $(1.3 \mathrm{~mm} / \mathrm{hr} \mathrm{m} / \mathrm{m})$ の条件Bは, 読み取り幅 $1.5 \mathrm{~mm}$ 以上に㧍ける平均誤差の増加と分布範囲の拡大が顕 著である。出水単位の誤差は, 読み取り幅 $2 \mathrm{~mm}$ の

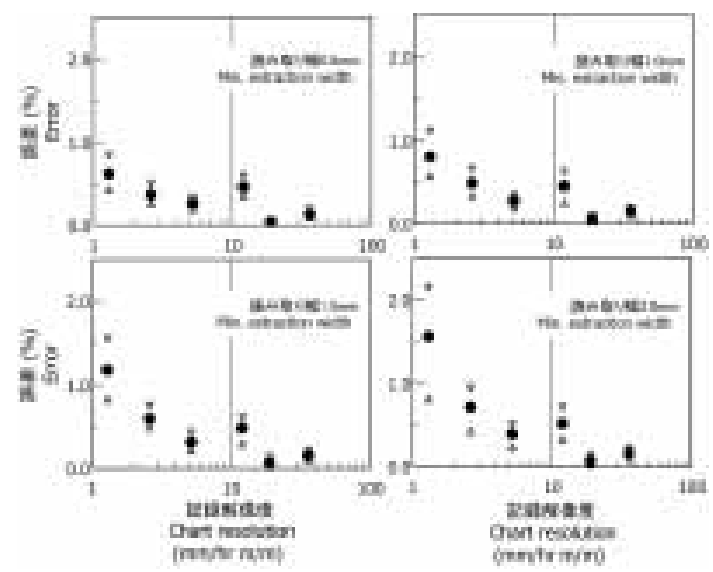

: 平均值, Mean value, $\nabla$ : 最大值, Maximum value, $\triangle$ : 最小 值, Minimum value.

図-8 読み取り幅に応じた記録解像度と年単位誤差の 関係

Fig.8 Relationships between chart resolutions (carriage speed $\times$ water-level magnification) and annual errors with variation of minimum extraction width shown.
時, 条件Bで最大 $42 \%$ を超える。誤差が最も小さい のは記録解像度が二番目に高い条件Aであり，記録 解像度が三番目に高い条件Fの誤差は, 読み取り幅 が小さいほど，記録解像度が低い期間条件の誤差と の差が縮まった。これをアスペクト比で整理すると 図一9となる。読み取り幅 $0.5 \mathrm{~mm}$ に打ける条件Dと

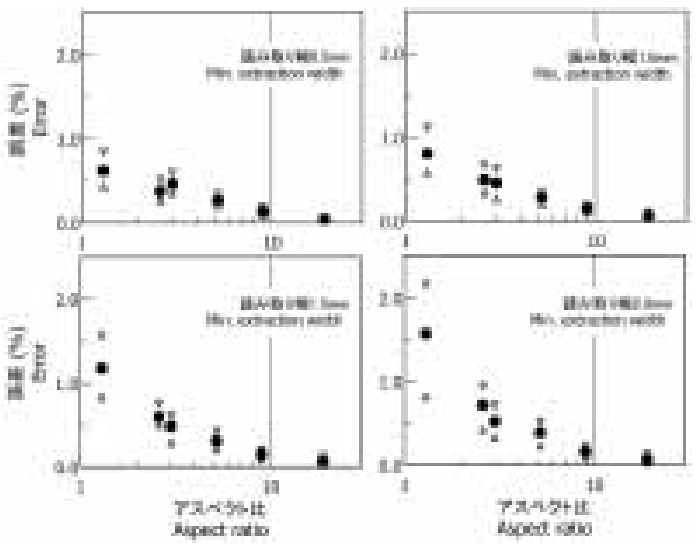

: 平均值, Mean value, $\nabla$ : 最大值, Maximum value, $\triangle$ : 最小 值, Minimum value.

図－9読み取り幅に応じたアスペクト比と年単位誤差 の関係

Fig.9 Relationships between the aspect ratios and the annual errors with variation of minimum extraction width shown. 
条件Fの関係を例外とすれば，アスペクト比が高い ほど，誤差は小さい傾向が認められた.

一方, 読み取り角を大きくすると, 読み取り幅を 大きくした場合とは逆に, 記録解像度が低い条件の 誤差はあまり変わらず，高い条件の誤差が大きくな る傾向が認められた (図一10). 出水単位の誤差の最 大值は, 読み取り角 $20^{\circ}$ の時でも $32.8 \%$ と, 読み取り 角 $2^{\circ}$ の場合とあまり変わらないが, 読み取り角が大 きくなると, 条件Bの值を他の期間条件の誤差が超 える出水も認められた. 特に条件Fの誤差は, 読み取 り角 $10^{\circ}$ 以上になると条件Bの誤差を上回る出水が増 加した。 また, 誤差の分布範囲は, いずれの期間条 件も読み取り角が大きくなるに従い広がった。これ をアスペクト比で整理すると図一11となる。アスペ クト比が高いほど誤差は小さい傾向が認められるも のの, 読み取り角が大きくなるとその傾向は弱まっ た. 条件Fの誤差は, アスペクト比が同程度の条件D の誤差よりも大きく増加した.

読み取り幅 $1 \mathrm{~mm}$, 読み取り角 $2^{\circ}$ の条件で, 正時読 みを加えない場合の年単位の誤差は, 最大 $2.3 \%$ とな り，正時読みを加えた場合に比べて全体に大きな值 を示した．正時読みの有無による誤差を比較すると， 期間条件により異なる傾向がみられた（図一12). 条 件Eでは正時読みの有無の影響がほとんど認められな いが，条件Aでは誤差に1.6〜 7.7倍の差が生じた。出 水単位の最大誤差は条件Aにおける62.8\%であり，条

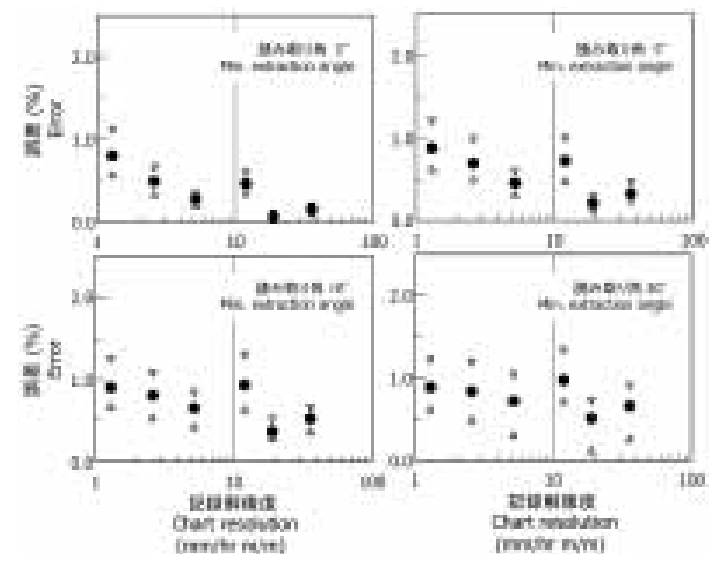

: 平均值, Mean value, $\nabla$ : 最大值, Maximum value, $\triangle$ : 最小 值, Minimum value.

図-10 読み取り角に応じた記録解像度と年単位䛊差の 関係

Fig.10 Relationships between the chart resolutions (carriage speed $\times$ water-level magnification) and the annual errors with variation of minimum extraction angle shown.
件Bの最大誤差 $34.7 \%$ よはるかに大きな值となっ た.また，条件Eを除き, 正時読みの有無による誤差 の倍率には，年による変動が認められた。
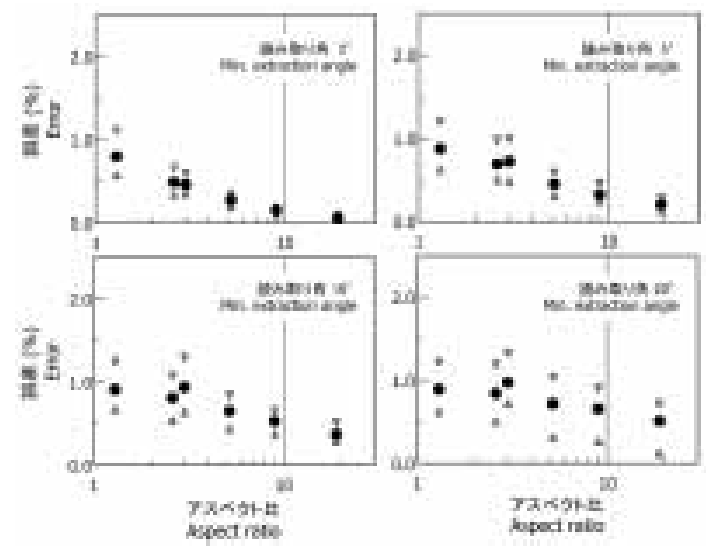

: 平均值, Mean value, $\nabla$ : 最大值, Maximum value, $\triangle$ : 最小 值, Minimum value.

図－11読み取り角に応じたアスペクト比と年単位誤差 の関係

Fig.11 Relationships between the aspect ratios and the annual errors with variation of minimum extraction angle shown.
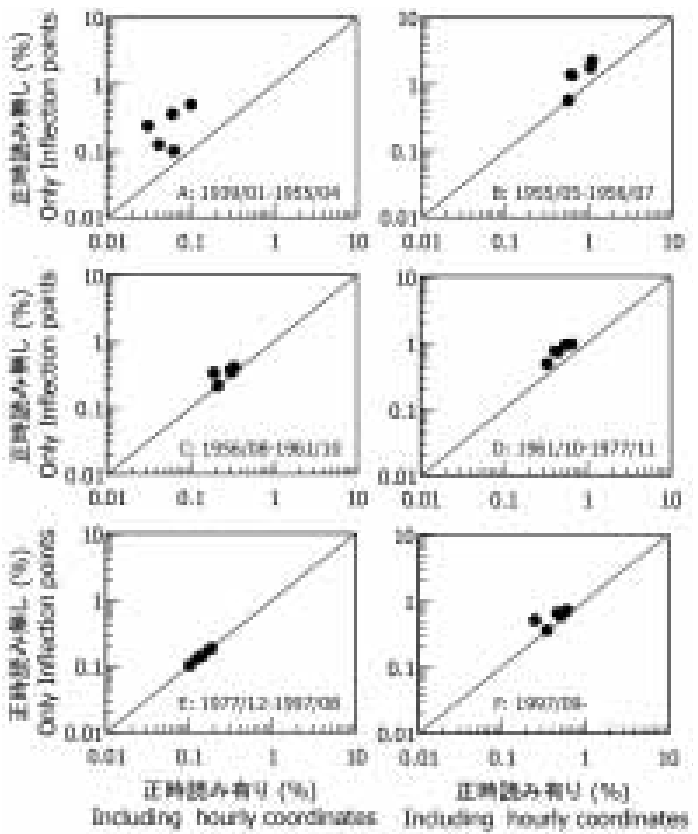

図-12 正時読みの有無と年単位誤差の関係

Fig.12 Relationships between the annual error including and excluding hourly coordinates, respectively. 


\section{V. 考察}

\section{1. 期間条件データ}

読み取り条件が一定でも，記録解像度により作成 される水位デー夕には差が生じた (図一3・4)。期 間条件データの作成に適用した読み取り条件は, 目 視による読み取りとしてはほぼ限界の条件である。 したがって，どんなに詳細に水位波形を読み取った としても, 記録解像度に応じた水位データの精度し か得られないといえる。このことは水位観測の精度 を確保する上で, 記録解像度の設定が重要であるこ とを意味する。記録解像度の影響は，単位時間当た りの水位変化 (水位変化率) が大きい出水ピーク周 辺で顕著であり，強い降雨による出水ほど記録解像 度の影響を受けやすいと考えられる。

\section{2. 誤差}

対象流域では例年8月に降水日数が少ない傾向が あり，植物の生育期でもあるため，年間の最低水位 をしばしば記録する。この時期に強い降雨がもたら された場合, 短時間に極端な水位変動が生じやすい. 5 月も年によっては降水日数が少なく，6・7・9月は 梅雨や台風の影響による比較的強い降雨がもたらさ れる. 10 月下旬〜 11 月は寒気の流入による強雨がも たらされることがある。これらの月は，大小の水位 変動が頻繁に繰り返される。12〜3月の降水は概ね 䨪・霰・雪のいずれかであり，すぐに流出に結びつ かないため, 水位変動は緩やかである. 月別の誤差 （図－5）と積雪期 · 非積雪期の期間誤差（図－7） は, こうした降水条件の季節的な特徵と, 水位変化 率が大きい出水ピーク周辺で記録解像度の影響が水 位データに現れやすい特性（図一3）を良く反映し ているといえる。つまり水位波形は, 降水の強度や 時間的な偏り，降水形態の影響を受けやすい。この ため, 年降水量が多いと年単位の誤差も大きい傾向 は認められるものの, 降水量が最も多かった2002年 の誤差は，2003・2004年ほどには大きくならなかっ たと考えられる (図一1・7).

水位波形を形状指数で整理すると, 形状指数 0.3 付近を境として誤差の分布に差が認められた（図一 6). 形状指数 0.3 未満で同じ形状指数に対する誤差 の分布範囲が広がるのは, 幾何学的に異なる形状の 波形が同一の形状指数を持ちうるためでもある。こ こで用いられる形状指数では，水位波形の形状を細 かく表現することはできないが, 形状指数 0.3 未満
の出水は, 記録解像度が低いほど大きな誤差を生む 可能性が高いと推察される.

記録解像度が低くなるほど, 特に水位変化率が大 きい部分の読み取り点数は少なくなる。読み取り点 数が減ることで, 出水の初期などで水位変化率が 徐々に増加する時（ピークの立ち上がり）や急な減 水過程では, 流出水量は過大評価され, 正值の誤差 が生じる，一方，急に増水してピーク付近で水位変 化率が緩やかに低下する場合, 流出水量は過小評価 され, 負值の誤差が生じる. 出水単位の誤差の正 值・負值の割合を年ごとに集計すると, 正值にな る出水は 46〜 $61 \%$, 負值になる出水は30～51\%で あった。対象期間を通じた比率は, 正值誤差の出水 が約 $10 \%$ 多い程度だが, 正值の誤差は負值の誤差 に比べて值の変動幅が大きい. 出水単位の誤差にお いて正值の割合が負值よりもやや多く, 変動幅も大 きいため年単位の誤差は正值となった。また記録解 像度の最も低い条件Bでも, 出水単位の誤差が5\% を超える出水の数は全体の6\%に満たないため, 年 単位の誤差は最大でも $1.2 \%$ 未満と, 出水単位の誤 差の最大值よりもはるかに小さな值になったと考え られる (図一7).

\section{3. 読み取り条件}

期間条件別に誤差を比較すると, 紙送り速度が大 きくなるほど誤差が小さくなる傾向が認められた (表一1, 図一5〜7). したがって紙送り速度だけで も記録解像度と誤差の関係を知る手がかりとなるだ ろう。しかし, 条件Cと条件Fの紙送り速度と誤差 の関係は例外を示した。このため水位倍率にも差が あることを考慮して，記録解像度およびアスペクト 比による検討を行った。

記録解像度で各期間条件の誤差を比較すると, 記 録解像度が高いほど誤差は小さい傾向が概ね認めら れた (図一8・10). 出水単位の誤差がほぼ0％とな る出水単位の数も, 記録解像度が最も高い条件 $\mathrm{E}$ 最も多い（誤差の絶対值が $0.001 \%$ 未満となる出水 は, 条件 $\mathrm{A}: 38$ 個, 条件B：2個, 条件 $\mathrm{C}: 18$ 個, 条 件D：10個, 条件E：199個, 条件F：11個). しかし ながらこの傾向は，記録解像度 $10 \mathrm{~mm} / \mathrm{hr} \mathrm{m} / \mathrm{m}$ 以上の 期間条件において一致しない場合がある。条件 $\mathrm{E} の$ 記録解像度は条件 $\mathrm{A}$ 約 2 倍あるにも関わらず，条 件Eは条件Aよりも誤差が大きかった。また，条件F の誤差は, 記録解像度約 $1 / 2$ の条件Cよりも大きく, 記録解像度約 $1 / 4$ の条件D と同程度であった。 
条件Eの誤差が条件 $\mathrm{A}$ 誤差を上回った理由は, 条件Eでは誤差が5\%前後になる出水が対象期間中 数例あった一方，条件Aでは $2 \%$ を超える誤差がひ とつの出水単位で生じたのみだったことによる (図一5・6). 条件Eに打ける5\%前後の誤差は，水 位変動率が大きい7９月の出水ピークの前後で単位 データの波形の再現性が悪い場合に生じた。また, 条件Aの抽出点は条件Eよりも少なく, 単位デー夕 の波形の再現性は条件Eに及ばないと考えられる （図一3）が，水位データが適度に間引かれたため出 水単位内での正負の誤差が相殺され䛊差が大きくな らなかったと推察される.

アスペクト比で各期間条件の誤差を比較すると, 読み取り幅 $1 \mathrm{~mm}$ 以上・読み取り角 $2^{\circ}$ の場合に各期間 条件の誤差は, アスペクト比が高いほど小さいとい える (図一9・11). 記録解像度では整理しきれなか った条件 $\mathrm{A}$ 条件 $\mathrm{E}$, 条件 $\mathrm{F}$ 条件 $\mathrm{C} \cdot$ 条件 $\mathrm{D}$ の誤差の 大小関係も，アスペクト比で整理すれば，この傾向 の中に収めることができる。ただし，読み取り幅を 小さくした場合・読み取り角を大きくした場合には, 条件Fの誤差が条件Dよりも大きくなった。

読み取り幅 $0.5 \mathrm{~mm}$ は条件Dでは約 12 分, 条件Fで は5分に相当する. 条件Dでは読み取り幅が小さく なるほど，単位デー夕の基本的な時間間隔 10 分 （図－4）に接近するため誤差が小さくなったと考え られる。一方, 条件Fでは読み取り幅が $1 \mathrm{~mm}$ よ小 さくなっても, 単位データの基本的な時間間隔より も細かい時間幅に相当するため, 䛊差は読み取り幅 $1 \mathrm{~mm}$ の場合とほとんど変わらなかった(図一8・9). このため読み取り幅を小さくした場合は, 条件Dの 誤差が減少して条件Fの誤差よりも小さくなったと 考えることができる。逆に，読み取り幅を大きくし た場合, 紙送り速度が小さい記録条件ほど自記紙上 の経過時間が長くなるため, 誤差は大きくなったと 考えられる。特に読み取り幅が自記紙上の 1 時間に 相当する幅を超えた場合, 誤差は大きく増加してい る。したがって対象流域では, 1 時間以内に生起す る水位変動を十分に捉えることができない紙送り速 度を用いると, 精度上問題があるといえる。一方, 紙送り速度 $18 \mathrm{~mm} / \mathrm{hr}$ 以上では読み取り幅を大きくし た影響がほとんど認められない。この記録解像度で は，十分に注意深く水位波形を読み取れば，大きな 誤差は生じないと考えられる。

読み取り角を大きくした場合, 条件F・条件Dとも に誤差は増加するが, 条件Fの方が増加率が大きい
(図一10・11). 条件D と条件Fの記録条件を比較する と, 水位倍率を等しくした場合, 条件Fの方が時間方 向に水位波形が拡張されることがわかる(表一1). 同じ水位倍率であれば，時間方向に拡張された水位 波形ほど変曲点の角度 $(\theta)$ が小さくなるため, 抽出 される変曲点の数が減少して誤差は大きくなると考 えられる。このため読み取り角を大きくした場合, 紙送り速度の小さい記録条件 $(3 \mathrm{~mm} / \mathrm{hr}$ 未満 $)$ の䛊差 はあまり変化せず, 紙送り速度の大きい記録条件 $(5 \mathrm{~mm} / \mathrm{hr}$ 以上) の誤差が増加したと考えられる (図一10・11).

以上を概観すると，アスペクト比は䛊差を考える 上で重要な記録条件であることがうかがえる、さら に紙送り速度に応じて, 読み取り条件を粗くした場 合の影響に差が生じると考えられた。しかし, 正時 読み無しの条件では，アスペクト比が最も高い条件 Aの誤差が最大であった（図一12）。これは，時間 方向のみ拡張される記録条件では, 正時読みを加え ない場合, 間点が十分抽出されずに誤差の変動が大 きくなるためである。一方, 記録解像度が最も高い 条件Eの誤差には正時読みの有無の影響がほとんど 認められなかった。このことから, 単にアスペクト 比を高くするだけでは誤差を小さくすることに結び つかないと考えられた。さらに, 記録解像度は $12 \mathrm{~mm} / \mathrm{hr} \mathrm{m} / \mathrm{m}$ 高いが, アスペクト比が3.0と低い 条件Fの誤差は, 記録解像度 $2.6 \mathrm{~mm} / \mathrm{hr} \mathrm{m} / \mathrm{m}$ ・アスペ クト比2.6の条件Dの䛊差とあまり変わらず，読み 取り条件によっては条件Dの誤差を上回った（図一 8〜11). これらの点を考慮すると, 読み取り条件 の影響を抑え, 誤差を小さくするためには, 記録解 像度とアスペクト比の両方が高い記録条件を用いる ことが必要と考えられた。ただし，正時読みを加え た条件では, 紙送り速度最大の条件Aにおける誤差 が常に最小であった（図一 5 11). 変曲点と正時 点を適宜読み取っている場合には, 水位波形が時間 方向のみ拡張される記録条件でも, 必ずしも大きな 誤差にならないことが示唆される.

\section{VI.まとめ}

水位計自記紙の記録解像度が流出水量の值に及ぼ す影響について, 釜淵1号沢における水位計の变遷 を例として検討した。その結果は次のように要約で きる。

(1) 期間条件データは記録解像度に応じて差が生じ 
た．特にピーク前後における間点の位置に記録 解像度の影響が顕著に現れた。

(2)このため出水単位の誤差は, 水位変動の大きい非 積雪期に変動幅が大きくなった。記録解像度が低 い条件では, 形状指数 0.3 未満の出水の誤差は大き くなる傾向が認められる。読み取り角 $2^{\circ} \cdot$ 読み取 り幅1 mmとしたとき, 記録解像度の最も低い条件 Bに打いて，誤差は最大 30 \%を超えた。

(3)一方, 出水単位の誤差が5\%を超えるのは, 条件 Bの場合でも全体の $6 \%$ に満たないため, 読み取 り角 $2^{\circ}$ ·読み取り幅 $1 \mathrm{~mm}$ の条件に拀ける年単位の 誤差は最大でも $1.2 \%$ 未満となった。同じ読み取 り条件に扔ける非積雪期の誤差は年単位の誤差よ りもやや大きな值を示し, 水位変動の緩やかな積 雪期の誤差は土0.1％の範囲に分布した.

(4) 読み取り条件を粗くすると誤差は大きくなるが, 読み取り幅を大きくした時の影響は低い記録解 像度・アスペクト比の記録条件で顕著であり, 読み取り角を大きくした時の影響は高い記録解 像度・アスペクト比の記録条件で顕著であった。 特に, 読み取り幅が自記紙上の1時間に相当する 長さを超えると誤差は大きくなる.

(5) 変曲点読みに正時読みを加えなければ誤差は大き くなる. 特に水位波形が時間方向のみ拡張された 条件Aでは, 読み取り角 $2^{\circ} \cdot$ 読み取り幅 $1 \mathrm{~mm}$ のと き, 出水単位における誤差の最大值が $60 \%$ を超え た。年単位の最大誤差は条件Bの $2.3 \%$ あっった。 本研究に抢いて基本とした読み取り条件（読み取 り角 $2^{\circ}$ 読み取り幅 $1 \mathrm{~mm} \cdot$ 正時読み有り）は，目視 による方法としては限界に近い.それでも記録解像 度に応じて以上のような誤差が生じた。実際の読み 取りは，作業効率にも配慮してさらに粗いことを考 慮すれば, 記録解像度に由来する誤差の変動幅はさ らに広がる可能性がある。しかし, 変曲点と正時を 適宜読み取っていれば必ずしも大きな誤差にならな いことが示唆されており, 正時読及無しの条件にお ける誤差の最大值が, 誤差の上限の目安となるだ ろう。

以上の結果から，釜淵1号沢に抒ける長期観測 データについて考えれば，年単位の流出水量を用い て観測期間を通じた解析を行う場合，補正を要する かどうかは目的に応じて判断すれば良いと考えられ る. 一方, 出水単位の流出水量を用いて観測期間を 通じた解析を行う場合, 水位変化率の大きい出水に 対しては, 記録解像度に応じた補正を検討する必要
があると考えられる。

釜淵森林理水試験地内の他の流域も釡淵 1 号沢と同 様の水位計の変遷を経ている. 1号沢を基準流域とし て, 対照流域法により長期的な流出変動の解析を行 う場合, 同じ記録解像度でも積雪期と非積雪期で誤 差の大きさが歴然と違うことを考慮すれば，流出特 性が少しずつ異なる釡淵各流域の流出水量の值に含 まれる誤差を等しいと仮定することには疑問がある. したがって他の流域についても本研究におけるよう な方法で記録解像度が流出水量に及ぼす影響につい て検討し, 補正の必要性を判断すべきであろう。

同様に，気候や集水面積，水位一流量曲線が異な れば，記録解像度の影響の現れ方に差が生じる可能 性は高い。記録解像度が低い条件で観測されていた 場合, 釜淵 1 号沢では多くの出水で流出水量の下方 修正が必要と考えられるが，流出水量を過小評価す る水位波形が多い流域では, 逆に流出水量の上方修 正が必要な場合も考えられる。さらに自記紙の読み 取り条件や流出水量の計算方法も様々であろう。立 地条件や観測条件の異なる流域の流出水量を細かい 時間精度で相互比較する場合も, 包含する誤差につ いて注意が必要である。

本研究では記録解像度と誤差の関係について示し たが, 長期観測データが内包する品質の摇らぎを克 服し, 細かい時間精度でも連続的な時系列として扱 えるようにするためには, 記録解像度に由来する䛊 差の補正方法を見出す必要がある。大きな䛊差が生 じる波形の特徵は, 本研究における解析を通してそ の概要が明らかとなった。図一6の関係についてさ らに検討を深め, 記録解像度の低いデー夕をいかに 補正し，記録解像度の高いデー夕とともに扱えるよ うにするか，その具体的な補正方法が今後の検討課 題である。

\section{謝辞}

釜淵における観測は, 先輩諸氏の努力により精度 が維持されてきた。栗田稔美氏，林野庁東北森林管 理局山形森林管理署最上支署には，現在の観測を支 援して頂いている．また，本稿を作成するにあたり 川村紀子氏には水位データの整理にご協力頂いた。 ここに記し感謝の意を表します。

\section{参考文献}

阿部敏夫・岸岡 孝・谷 誠 (1982) : 山火事の直接流出に及ぼす影響 について, 日本林学会関西支部第33回大会講演集, pp.197200. 
細田育広・村上 亘 (2006): 釜淵森林理水試験地観測報告-1・2号 沢試験流域一(1994年1月～2000年12月), 森林総合研究所研 究報告, No.398, pp.99-118.

神田徹・藤田睦博 (1982): 水文量の頻度解析, 新体系土木工学 26水文学, 技報堂出版, pp.13-75.

木下武雄 (2004) : 自然災害研究のための利用可能データ, 統計数 理, 52 (1), pp.5-24

蔵治光一郎 (2003) : 森林の緑のダム機能 (水源かん養機能) とそ の強化に向けて. 森林の公益的機能新解説シリーズ 3 , 日本治 山治水協会, pp.4.

丸山岩三・猪瀬寅三 (1952) : 釜淵森林理水試験第1回報告, 林業試 験場研究報告, No.53, pp.1-44.

野満隆治・瀬野錦蔵 (1959): 水位とその変化, 新河川学, 地人書 館, pp.68.

農林省林業試験場 (1961) : 東北支場山形分場 (釜淵森林理水試
験地）1939年1月～1958年12月，森林理水試験地観測報告, pp.68-69.

Stevens Water Monitoring Systems, Inc. 1998. Errors in floatoperated devices. Water Resources Data Book ( $6^{\text {th }}$ Edition), Stevens Water Monitoring Systems, Inc.: Beaverton, Oregon. 97-124.

高橋 裕 (1978): 河川水文学, 共立出版, pp.37.

山口高志・斎藤秀晴 (1997) : 6.1 概説, 水文・水資源ハンドブック (水文・水資源学会編), 朝倉書店, pp.178-181.

吉野文雄 (1997)：6.5 流量観測, 水文・水資源ハンドブック（水 文・水資源学会編), 朝倉書店, pp.192-193.

Yue S, Ouarda TBMJ, Bobee B, Legendre P, Bruneau P. 2002. Approach for describing statistical properties of flood hydrograph. Journal of hydrologic engineering 7 (2) : 147153.

（受付：2006年8月9日，受理：2007年6月8日）

\title{
Effect of Chart Resolution of Water-level Gauge on Runoff Values
}

\author{
Ikuhiro HOSODA ${ }^{1)}$ Wataru MURAKAMI ${ }^{2)}$ Roy C. SIDLE ${ }^{3)}$ \\ 1) Kansai Research Center, Forestry and Forest Products Research Institute \\ (Fushimi, Kyoto, 612-0855 Japan) \\ 2) Forestry and Forest Products Research Institute \\ (Tsukuba, Ibaraki, 305-8687 Japan) \\ 3) Geohazards Division, DPRI, Kyoto University \\ (Uji, Kyoto, 611-0011 Japan)
}

The effect of chart resolution (carriage speed and water-level magnification) of a water-level gauge at the outlet of Kamabuchi No.1 experimental watershed on runoff values was examined for a long-term record dating back to 1939. Recent water-level data (original data) were transformed into actual scale coordinates depending on chart resolutions in the past. Then inflection points and hourly coordinates were extracted from the waveforms as transformed water-level data (extracted data) with defined minimum extraction widths and angles. Error was defined as the difference between runoff calculated from the extracted data and the original data, respectively, and was expressed as a percentage of the original data. The effect of chart resolution was very apparent around the peak of the waveform. Since water-level fluctuations are large in the seasons without snow, the range of error becomes larger with lower chart resolution. Unit flood errors increased when the shape index was $<0.3$. Even if the waveform was carefully traced, maximum unit flood error exceeded $30 \%$ in contrast to annual error which was always $<1.2 \%$. Therefore when long-term changes in runoff are analyzed in this study site, it appears possible to use annual runoff data without corrections. However, runoff data of shorter time scales, such as unit flood runoff, should be corrected based on the chart resolution.

Key words : chart resolution, aspect ratio, shape index, long-term observation, data quality 